\title{
What national governance codes say about corporate culture
}

\author{
Marie-Fleur Lobrij, Muel Kaptein and Mijntje Lückerath-Rovers
}

\begin{abstract}
Purpose - This study aims to provide insight into the current incorporation of corporate culture in national corporate governance codes. The authors identify three levels of incorporation for each of the following three dimensions: layers of corporate culture (the "what"), the alignment of corporate culture in the organization (the "for whom") and the board's roles regarding corporate culture (the "how").

Design/methodology/approach - To assess the extent to which national codes have incorporated corporate culture, the authors used a sample of 88 national corporate governance codes. The authors performed a content analysis of these codes using a computer-aided text analysis program. The first step involved the identification of dimensions of corporate culture per national code. These dimensions were then assessed based on three levels of incorporation. Finally, the authors ranked national codes with similar levels of incorporation per dimension and aggregated the dimensions.

Findings - The data show that five of the 88 national corporate governance codes that the authors analysed scored the highest level in all three dimensions of corporate culture.

Originality/value - This is the first study to provide an overview of what national corporate governance codes say about corporate culture. The authors address two gaps in the existing literature. First, the authors develop and use a richer conceptualization of how corporate culture can be addressed in national corporate governance codes. Second, the authors analyse these corporate governance codes worldwide.
\end{abstract}

Keywords Organizational culture, Corporate culture, Organizational climate, Informal governance, Corporate governance code

Paper type Research paper

\section{Introduction}

In 2017, the revised Dutch corporate governance code for listed companies in The Netherlands came into force. One of the major changes in this code, compared to the previous version of 2008, was the introduction of the concept of culture. The revised code requires companies to create a culture that promotes desired behaviour within the corporation. It states that the executive board "should adopt values for the company and is responsible for the incorporation and maintenance of the values within the company" ( $p$. 26). The code also states that both the executive board and the supervisory board are responsible for "stimulating openness and accountability within the organ of which they form part and between the different organs within the company" (p. 24). The introduction of the concept of culture in the Dutch corporate governance code raises the questions of why corporate culture is a relevant corporate governance concept and to what extent other national corporate governance codes currently incorporate this concept.

In the corporate governance literature, the relevance of corporate culture is described in relation to the role modelling of boards and in relation to the performance of corporations. In relation to the role modelling of boards, several academics advocate the responsibility of boards for shaping and ensuring the right corporate culture by the board's behaviour. For example, Soltani (2014) argues that board members should set the right "tone at the top",
Marie-Fleur Lobrij and Muel Kaptein are both based at the Rotterdam School of Management, Erasmus University, Rotterdam, The Netherlands. Mijntje Lückerath-Rovers is based at TIAS School for Business and Society, Tilburg University, Tilburg, The Netherlands.

Received 15 August 2019 Revised 27 November 2019 24 April 2020

Accepted 14 May 2020

(C) Marie-Fleur Lobrij, Muel Kaptein and Mijntje Lückerath-Rovers. Published by Emerald Publishing Limited. This article is published under the Creative Commons Attribution (CC BY 4.0) licence. Anyone may reproduce, distribute, translate and create derivative works of this article (for both commercial and non-commercial purposes), subject to full attribution to the original publication and authors. The full terms of this licence may be seen at http://creativecommons. org/licences/by/4.0/legalcode

The authors would like to thank the participants in the 33rd EGOS Colloquium and Wempe for their useful comments on an earlier version of this article. 
and therefore, should have the correct personal values because corporate failures are related to the failure of the tone at the top. Webley and Werner (2008) assert that the board's behaviour is crucial in integrating the corporate culture into the strategy and processes of the corporation. Haspeslagh (2010) identifies four roles of boards, one of which is setting the tone at the top, which consists of shaping the values of the corporation and ensuring that they are brought to the coalface. The relevance of corporate culture is also described in relation to the performance of corporations. A variety of studies show that corporate culture is an important factor for the successful financial and non-financial performance of corporations (Guiso et al., 2015; Kotter, 2008; Sorensen, 2002).

Despite the importance of corporate culture in the governance of firms, most studies on the content of national corporate governance codes focusses on its non-cultural elements, namely, the formal governance mechanisms (Yang, 2011). Research on formal governance mechanisms concentrates on, for example, how the codes address shareholders' rights (Ferrero Ferrero and Ackrill, 2016; Hermes et al., 2006; Kubícek et al., 2016) and how companies follow regulations on accounting and disclosure (Cicon et al., 2012). The studies that do concentrate on the incorporation of corporate culture in national corporate governance codes are limited in scope. These studies focus on just one element of the corporate culture. Soltani and Maupetit (2015) study the value of ethics and Wieland (2005) studies the different values in codes without assessing other elements of corporate culture such as norms and responsibilities. Furthermore, these studies have limited samples. Soltani and Maupetit (2015) analyse the codes of five European countries and Wieland (2005) analyses the codes of 22 European countries.

To get a better insight into the current incorporation of corporate culture in national corporate governance codes, this article uses a richer conceptualization of corporate culture, instead of only values and, analyses codes worldwide, instead of only European codes. We will develop a multi-layer model for assessing the level of incorporation of corporate culture in corporate governance codes and then apply the model to 88 different national codes. In that sense, we contribute to the current literature by exploring to what degree corporate culture (firm-level) is incorporated into national corporate governance codes (country level). However, we do not study here the relationship between national culture and national codes, nor the relationship between national codes and the culture of corporations, which are directions for future research based on our current research.

\section{Towards a model of the incorporation of corporate culture in codes}

Based on the literature on corporate culture, we can distinguish among three dimensions of corporate culture that are relevant in assessing national corporate governance codes (from here on: "codes"). These dimensions, which we will successively discuss, are layers of corporate culture, alignment of corporate culture in the organization and the board's roles regarding corporate culture. We will then present these three dimensions and their operationalization as the dimensions of our model for studying how corporate culture is addressed in national codes.

\section{Dimension 1: layers of corporate culture}

Prototypical models of corporate culture have been developed by, for example, Schein (1984), Allaire and Firsirotu (1984), Hatch (1993) and Cameron and Quinn (2005). One aspect that these models have in common is that corporate culture is defined in terms of values, norms and behaviour. These three layers can also be used to assess what layers of corporate culture are addressed in national codes.

Values can be defined as the overarching criteria that people use or should use to make choices (Etzioni, 1988). Values are referred to by Gundry and Rousseau (1994) as the least perceptible layer of corporate culture. In the corporate setting, values are a set of shared 
beliefs about how employees should serve the stakeholders of their corporation (Verhezen, 2010) and refer to the qualities that corporations deem desirable and that should ground all behaviour of employees (Kaptein and Wempe, 2002). For Schwartz and Davis (1981), values are the roots of corporate culture because they create, situational norms that are evidenced in observable behaviour. Examples of corporate values are entrepreneurship, integrity, transparency and flexibility (Kaptein, 2004).

Norms can be defined as the concrete criteria that people use or should use to make choices. O'Reilly et al. (1991) define norms as social expectations based on underlying values. According to Gibbs (1965), a norm also involves an external sanction as a specific reaction to behaviour that is inconsistent with social expectations. Those behaviours that ensure collective survival, facilitate task accomplishment, contribute to the collective morale or express mutual central values are likely to be brought under normative control (Feldman, 1984). Examples of norms in the corporate setting are expectations of how people should deal with conflicts of interest, confidential information and each other (Kaptein, 2004).

The third layer of corporate culture, behaviour, is about what people do or should do. Behaviour is, as Gundry and Rousseau (1994) define it, the most perceptible and most concrete layer of the corporate culture. Behaviours are related to underlying meanings (Verbeke et al., 1998) and those meanings, the values and norms, affect what types of behaviour are considered desirable and acceptable (Lai et al., 2013). In a comparative analysis of American and European corporate scandals, Soltani (2014) states that the promotion of undesirable behaviour to subordinates was one of the characteristics of corporate malfeasance.

\section{Dimension 2: alignment of corporate culture in the organization}

In addition to assessing what layers of corporate culture are addressed by national codes, it is also relevant to assess to whom these layers apply. Ardichvili et al. (2009) found that building and sustaining a corporate culture requires desired behaviour to permeate throughout all layers of the corporation, from board members and management to frontline employees. Denison et al. (2003) refer, in this respect, to the cultural trait of what they call consistency, which they define as a powerful source of stability and internal integration resulting from a common mind-set. Research by Harris and Mossholder (1996) and Posner et al. (1985) supports the concept that better alignment results in a better performance of and within corporations.

Alignment is how we label the second dimension of the incorporation of corporate culture in codes. We define the alignment of organizational culture as a shared understanding of the values, norms or behaviour of the organization as a whole or between one or more layers within the organization. When we can make a distinction between the hierarchical layers of a board (executive or managing and, when existing, also supervisory), management (senior, middle and low layers) and employees (front and back office), the measure of codes in this respect is whether they address the corporate culture for one, two or all three hierarchical layers.

\section{Dimension 3: the board's roles regarding corporate culture}

A third dimension of the incorporation of corporate culture in national codes is the board's roles regarding corporate culture. This dimension is separate from whether culture is defined in three or fewer layers (Dimension 1) and from whether culture is defined for three or fewer hierarchical layers within the organization (Dimension 2). Describing the board's roles regarding corporate culture in codes is important because corporate governance refers to the distribution of rights and responsibilities among the different actors involved in the corporation (Aguilera and Jackson, 2003). The board, whether onetiered or two-tiered, plays an important role in shaping and ensuring the appropriate 
corporate culture (Treviño et al., 2000). It can have different roles in this aspect, which is a measure of the activities that a board should perform according to a code.

The first type of role that a board should play is defining the culture of their corporation. Because the corporate culture should be tailored to the corporation (Collins and Porras, 2005), codes may prescribe that boards should formulate what the desirable corporate culture is. Formulating and making explicit the desirable values, norms and behaviour is an important element of leadership (Brown et al., 2005; Schein, 2010). The second type of role that a board should play is that once the desirable culture is defined, the board should ensure that it is implemented and embedded in the corporation, for example, by role modelling (Soltani, 2014), by integrating culture into the strategy and processes of the corporation (Webley and Werner, 2008), by using a corporate culture programme (Silverzweig and Allen, 1976) and by communicating the desirable culture within the corporation (Brown et al., 2005). The third type of role for the board is the monitoring of corporate culture. Haspeslagh (2010) notes that boards play the role of ensuring that the desired culture is implemented and embedded. For that purpose, the board should monitor the corporate culture and evaluate the results. In that case, codes can also require boards to report the results of their monitoring to stakeholders to inform them about the current corporate culture. For example, Osma and Guillamón-Saorín (2011) argue that effective governance is associated with greater disclosure of relevant information. Thus, when information about the corporate culture is assumed to be relevant, codes can require corporations to disclose that information.

\section{A model of incorporation of corporate culture in codes}

The three dimensions of corporate culture that we have explored above can be used to analyse the extent to which corporate culture is incorporated in codes. For each of these dimensions, we can distinguish three levels of incorporation in codes, namely, the minimal, medium and advanced level based on whether one, two or all three elements per dimension are addressed in code. Table 1 shows these elements for each dimension. The identification of levels corresponds to comparable research. For example, Maier and Schmidt (2015) use a four-level maturity model in performing qualitative analyses on organizational knowledge creation. In our model, national codes can range from a total level, when the levels of the three dimensions are aggregated, of 0 (with no level for each of the three dimensions) to 9 (with the advanced level for each of the three dimensions). In the latter case, the national code addresses all three main layers of corporate culture (values, norms and behaviour), addresses all three main hierarchical layers in the corporation (board(s), management and employees) and addresses all three of the board's main roles regarding corporate culture (defining, implementing and monitoring).

\section{Method}

To assess the extent to which national codes have incorporated corporate culture, we used a sample of the most recent 88 national codes. We retrieved the codes from the website of the European Corporate Governance Institute (ECGI) (http://ecgi.org) on 31 July 2017 and

\section{Table 1 Operationalization of incorporation of corporate culture in codes}

\begin{tabular}{lll}
$\begin{array}{l}\text { Layers of } \\
\text { corporate culture }\end{array}$ & $\begin{array}{l}\text { Alignment of corporate } \\
\text { culture }\end{array}$ & $\begin{array}{l}\text { Board's roles regarding corporate } \\
\text { culture }\end{array}$ \\
\hline Values & Board(s) & Defining \\
Norms & Management & Implementing \\
Behaviour & Employees & Monitoring
\end{tabular}


used only the codes for which an English translation was available at that time. The 88 codes that we analysed are shown in the Appendix. Our sample consisted of national codes for both listed or unlisted for-profit companies. The sample represented 32 OECD and 56 non-OECD countries, 27 members and 61 non-members European union states and 21 members and 67 non-members of the Commonwealth.

We performed a content analysis of these codes using a computer-aided text analysis program (NVivo) to more easily compare the results across texts. NVivo is one of the options for storing, managing and analysing qualitative data. We have chosen NVivo, as opposed to other software because of its wide range of features such as journaling, mapping tools, visualization techniques (Jackson and Bazeley, 2019) and user-friendliness. The units of data or identifiable messages or message components (Neuendorf, 2002) were words, sentences and paragraphs and the content analysis consisted of three steps.

The first step was an identification of the dimensions of corporate culture per national code distinguished in our model. Second, these dimensions were assessed on three levels of incorporation. For both of these steps, we started with using our coding scheme to individually assess and pre-test a random group of five codes independently of each other. Then, we compared the results of our analyses and revised the coding scheme where necessary. The first author performed the analysis of the other codes, which was again reviewed by the two other authors. As a third step, we established a ranking of national codes with a similar level of incorporation per dimension and aggregated the dimensions. During the process of developing the final coding scheme, a draft was presented to a group of governance experts at an international conference. Their insightful comments were used to further improve the coding scheme.

The main themes of this coding scheme were determined through a review of the literature on both corporate culture and governance. The three dimensions of corporate culture (i.e. layers of corporate culture, alignment of corporate culture in the organization and the board's roles regarding corporate culture) were then operationalized to assess the extent to which corporate culture had been incorporated. Regarding layers of corporate culture, this resulted in literally stating the concepts or actual examples of these layers. The alignment of corporate culture was conceptualized as explicit similarities among layers of corporate culture held by the board(s), management and employees. The third dimension, the board's roles regarding corporate culture, was operationalized in assigning responsibility to the board(s) to define, implement or monitor corporate culture.

All codes were first fully reviewed and analysed according to the coding scheme before importing them into NVivo. For each of the three dimensions of corporate culture, a group or main node was created. Then, sub-nodes for operationalized levels of the incorporation of corporate culture were created for each of the three dimensions to establish a hierarchy. The analysed code content was then dragged from the imported files to the corresponding node. As a result, we were able to compare the results across codes.

Regarding the dimension of the layers of corporate culture, codes that address one of these layers can be positioned on level one, the minimal level of the layers of corporate culture; codes that address two layers can be positioned on level two, the medium level of the layers of corporate culture; and codes that address all three layers can be positioned on level three, the advanced level of the layers of the corporate culture. Codes that do not address even one of these layers can be positioned on the lowest level, i.e. level zero. Different levels of the dimension of alignment of corporate culture can be indicated by whether a code addresses one hierarchical layer within a corporation (minimal level), two hierarchical layers (medium level) or three hierarchical layers or the corporation as a whole (advanced level). Lastly, in regard to the dimension of board's roles regarding corporate culture, codes that address one of the board's roles can be positioned on the minimum level, codes that address two types of roles 
can be positioned on the medium level and codes that address all three types of roles can be positioned on the advanced level.

\section{Results}

The assessment of all codes in each dimension and at each level of incorporation is presented in Table 2, whereas the Appendix shows, in alphabetical order, the level of incorporation per dimension per national code. Below, we illustrate all levels per dimension with an example, identify the national codes with advanced incorporation in all dimensions ("best practice" codes) and conclude by analysing the overall level of incorporation for each code and cluster of codes.

\section{Layers of corporate culture}

All 88 codes address two or three layers of corporate culture. The code of Georgia is an example of two layers that are mentioned. Regarding behaviour, this code states that "managers [...] must behave as a reasonably prudent person would act in similar circumstances and believe that such behaviour is in the best interests of the company" (p. 5) and regarding values, this code explicitly refers to the concept of values, "[...] Framework of values [...]" (p. 10). While 30 codes address two layers, 58 codes address all three layers of corporate culture. An example of the latter is the code of Australia, which describes culture: "[...] creating a culture within the entity that promotes ethical and responsible behaviour [...]" (p. 19); values: "[...] a listed entity's code of conduct must be and be seen to be, a meaningful statement of its core values. [...]" (p. 19); and, finally, a norm: "it needs to be promoted as such across the organization and reinforced by proper training and proportionate disciplinary action if it is breached" (p. 19). In this case, sanctioning is specified as a consequence of breaching a code of conduct.

Notably, all codes assessed as having incorporated three layers of corporate culture state norms, while codes assessed as having incorporated two layers of corporate culture name only values and behaviour. In most national codes that do mention a norm, the reason for sanctioning differs but is most commonly poor performance, a restatement of the financial accounts of previous years (both of which appear in 12 codes) or a conflict of interest (in six codes). The least mentioned reasons for sanctioning are, for example, the absence of board members from meetings (in two codes); previous conviction of a crime; undermining the environment, health or safety; or breaching code of conduct (all in one code).

\section{Alignment of corporate culture}

Of the 88 analysed codes, 24 codes were identified as describing the alignment of the corporate culture at least at one hierarchical layer of the organization. However, the majority (64 codes) did not refer to the alignment of the organizational culture at all within (layers of) the organization. The only code where one hierarchical layer is described is the code of Czech Republic: "the development of a collegiate spirit amongst the executive board members is highly desirable" (p. 47). Six codes describe two hierarchical layers such as the

\section{Table 2 Results of codes assessed $(n=88)$}

\begin{tabular}{lccc} 
Dimension & $\begin{array}{c}\text { Layers of } \\
\text { corporate culture }\end{array}$ & $\begin{array}{c}\text { Alignment of } \\
\text { corporate culture }\end{array}$ & $\begin{array}{c}\text { Board's roles regarding } \\
\text { corporate culture }\end{array}$ \\
\hline No incorporation & 0 & 64 & 56 \\
Minimal incorporation & 0 & 1 & 13 \\
Medium incorporation & 30 & 6 & 9 \\
Advanced incorporation & 58 & 17 & 11
\end{tabular}


code of Hong Kong: "the board [...] should clarify the standards of ethical behaviour required of directors and executives and encourage adherence to those standards" (p. 49). In total, 17 codes describe three hierarchical layers such as the code of Pakistan: "the board of directors of a listed company shall ensure that as follows: professional standards and corporate values are put in place that promote integrity for the board, senior management and other employees [...]" (p. 7). Interestingly, all six codes that describe two hierarchical layers do not address employees.

\section{Board's roles regarding corporate culture}

A total of 33 national codes explicitly name one or more roles for boards regarding corporate culture, while 55 codes do not describe any roles. In total, 13 of these 33 codes state only one role of the board regarding corporate culture; for example, the code of Sweden mentions only the setting of guidelines: "the principal tasks of the board include [...] defining appropriate guidelines to govern the company's conduct in society [...]" (p. 16). Nine codes of the 33 state two roles of the board regarding corporate culture such as the code of Barbados: "the board has overall responsibility for [...] including approving and overseeing the implementation of the strategic objectives, risk strategy, corporate governance framework and corporate values" (p. 2). Finally, 11 codes of the 33 state all three roles of the board. In this group, the codes of Brazil, Jordan, The Netherlands and South Africa refer explicitly to defining, implementing and monitoring corporate culture. The code of Brazil even adds corrective measures in case of deviation: "the executive management should promote the corporate culture, strengthening its values and principles, applying them in formal policies, practices and procedures. In addition, it should devise ways for it to permanently monitor whether its decisions, actions and impacts are aligned with such values and principles. In case of deviations, it should propose the application of corrective and, ultimately, punitive measures, as provided by the code of conduct" (p. 70).

\section{Overall level of codes}

When we calculate per code the aggregated level for the three dimensions together and group the codes at the same aggregated level, we see, as shown in Table 3, that the clusters range from two to nine levels. Five codes, those from Brazil, Jordan, The Netherlands, New Zealand and the UK, have the highest level, meaning that they have advanced incorporation for all three dimensions. These codes mention the three layers of corporate culture, the alignment of corporate culture between the three organizational layers and the three roles of the board regarding corporate culture.

In comparing the results of the clusters of codes, we notice three prominent differences. First, the difference in ranking between clusters with an aggregated level of eight and nine lies only in the role of the board in monitoring the corporate culture. Second, almost all codes in the cluster with an aggregated level of three have an advanced level in the layers

\section{Table 3 Clusters of codes $(n=88)$}

\begin{tabular}{lcc} 
Aggregated level & No. of codes & \% of codes \\
\hline 2 & 22 & 25 \\
3 & 27 & 31 \\
4 & 9 & 10 \\
5 & 7 & 8 \\
6 & 9 & 10 \\
7 & 5 & 6 \\
8 & 4 & 4 \\
9 & 5 & 6
\end{tabular}


of corporate culture that are addressed and no level in the alignment of corporate culture and the board's roles regarding corporate culture. Only the codes of Finland and the Maldives state one role of the board regarding corporate culture. This is also the case, which is the third prominent difference that we want to point out, for national codes in the cluster with an aggregated level of two. These are all codes that have no incorporation of alignment of the corporate culture and the board's roles regarding corporate culture.

\section{Discussion and conclusion}

We began this article by suggesting that research on the content of national corporate governance codes could benefit from addressing corporate culture. The extant research on the content of these codes mainly focusses on formal mechanisms. Although several authors in the field of corporate governance acknowledge the role of the board in managing corporate culture (Haspeslagh, 2010; Soltani, 2014; Webley and Werner, 2008), no research on the various dimensions of corporate culture in national codes has been conducted to date.

We developed a multi-dimensional model to assess the content of national codes in terms of the incorporation of corporate culture. We distinguished three dimensions of corporate culture: layers of corporate culture, alignment of corporate culture in the organization and the board's roles regarding corporate culture. Our model defined three discrete levels of incorporation per dimension and we performed a content analysis of 88 national codes using the model. The results of the assessment of individual codes and the clustering of these codes showed distinct differences and five "best practice" codes.

Our results indicated at least two remarkable findings. We found that only advanced codes add employees as the third layer in the alignment of the corporate culture. This finding is remarkable, as employees play an important role in building a distinctive corporate culture (Canals, 2014), corporate culture provides clues to employees on how to behave and what is acceptable (Brad Shuck et al., 2011) and aligning values across all work sessions leads to a strong corporate culture (Markos and Sridevi, 2010). We also found that only the five "best practice" codes describe the boards' involvement in defining, implementing and monitoring corporate culture. This result is remarkable because boards are expected to play an important role in defining, implementing and monitoring the culture or their organization. In addition, corporate culture impacts the effectiveness of boards (Fiordelisi and Ricci, 2014; Nicholson and Kiel, 2004) and the effectiveness of their organizations (Guiso et al., 2015; Kotter, 2008; Sorensen, 2002).

\section{Avenues for future research}

This study opens avenues for future research. The first avenue concerns the extension of our sample. Some codes such as the national code of Israel were neither available in an English translation nor published on the website of the ECGI. This lack of data availability restricted our sample, which means that our results do not present a complete overview of all national codes. It may, therefore, be of great value to include more national codes to obtain a better understanding of the extent to which national codes incorporate corporate culture.

A second avenue for future research relates to the improvement of our model with more dimensions and in more detail. We developed a model with three dimensions consisting of three elements each. However, other dimensions might also be relevant. For example, it might be relevant to distinguish between corporate cultures oriented towards achieving economic and ethical goals (Donaldson and Walsh, 2015) and that aim to address different stakeholders (Jones et al., 2007). Additionally, the scale per dimension could be more specific. For example, it might be relevant to divide the current element of monitoring 
corporate culture into measuring corporate culture, auditing corporate culture and reporting about corporate culture.

A third avenue for future research is to conduct more empirical studies on the content of national corporate governance codes. Although we reported interesting empirical findings, many more analyses are possible at the country level using data on how national codes address corporate culture. For example, future research could explore the differences in how codes incorporate corporate culture between continents, examine whether and how the incorporation of corporate culture relates to other topics in national codes, focus more on the proportions and details of the elements of the dimensions described in codes and account for additional country-level variables (such as political, legal or economic clusters) when comparing national codes in terms of the incorporation of the corporate culture. Future research could also focus on the development of the incorporation of corporate culture in national codes overtime or on the reciprocal effects of governance mechanisms and corporate culture.

Another research avenue relates to the antecedents of the incorporation of corporate culture in national corporate governance codes. An important antecedent could be the national culture of the issuing country (Agyei-Mensah, 2017; Alazzani et al., 2017; Azam et al., 2019; Haxhi and Van Ees, 2010; Humphries and Whelan, 2017; Karlsson et al., 2018; Li and Harrison, 2008; Sabbaghi 2016; Schonfelder et al., 2016). Researchers can explore the effects of national culture on the content of national codes in various ways. National culture could relate to the three dimensions of corporate culture in the codes we distinguished in our model as follows: layers of corporate culture, alignment of corporate culture in the organization and the board's role in corporate culture. Furthermore, researchers could aim to illustrate the literal statements of national culture in national codes, like "apartheid" in the code of South Africa (2009, p. 13) or a Māori custom in the code of New Zealand (2015, p. 3). These codes link examples of national culture to desired behaviour at the firm level. Lastly, dimensions of national culture such as power distance or uncertainty avoidance (Hofstede, 1983) could be related to national codes and researchers could conduct an international comparison to study the relationship between national and corporate culture as incorporated in national corporate governance codes.

A final avenue for future research could focus on the compliance of organizations with the applicable national corporate governance codes and the effectiveness of compliance in terms of performance. The incorporation of corporate culture in national codes does not say anything about whether companies indeed support and adopt the content of governance codes and comply with it. Future research can determine the opinions and measure the support of company board members on the expectations of the national corporate governance code in terms of the corporate culture. Such a study could also determine the extent to which boards comply with these expectations using a survey of employees (Kaptein, 2011) and analysing annual reports. Such research should account for the different enforcement mechanisms of national codes (through soft regulation or legal enforcement). It could then also be interesting to explore whether the incorporation of corporate culture in national codes and the adoption by companies actually affects the financial and non-financial performance of these companies.

\section{Practical implications}

Our study has at least four implications for practice. First, our study relates to the generic development of national codes. Our results highlight that national codes that incorporate corporate culture at a high level differ in three ways from national codes with lower levels of incorporation. Higher-level codes describe norms as a layer of corporate culture, include employees' alignment with corporate culture and describe more roles of the board regarding corporate culture. The implication for practice is that these three differences 
show the general direction that lower-level codes can take to increase the level at which they incorporate corporate culture.

The second implication concerns the specific development of a national code. Our conceptualization and operationalization of the incorporation of corporate culture in national codes might assist regulators and policymakers in evaluating their codes when they consider revisions. Regulators and policymakers can use the model to assess their current codes and based on that assessment, decide how to improve their codes. Our model shows the potential direction of code when the aggregated level needs to be higher. The concrete examples from the 88 national codes that we collected in our study can be a source of inspiration for policymakers who want to improve their codes.

The third implication relates to the use of our results as a basis for country-level decisions. Our study shows the extent to which national corporate governance codes currently incorporate corporate culture. The Appendix provides the scores for each country. The attention to corporate culture in national codes could indicate the extent to which a country has an awareness that corporate culture is important, that it is important to manage corporate cultures and that company boards have an important role in this. Prior research shows that better management of corporate culture leads to better performance for the company (Kaptein, 2011), suggesting that the more a national code incorporates corporate culture, the better the country's companies will perform. Decision-makers in international business and finance could, therefore, benefit from our assessment of national codes when considering foreign direct investments, for example.

The final implication of this study relates to the boards of companies. This study focussed on the content of national corporate governance codes and their prescriptions for boards in terms of what they could or should do in managing the culture of their organizations. Next to following the applicable codes, boards could also use our model as it presents guidelines when the applicable codes do not meet all dimensions in our model. Boards can then use the model to determine whether they manage their corporate cultures in terms of the three conceptual layers (values, norms and behaviour), three groups (themselves, management and employees) and their three roles (defining, implementing and monitoring). Boards that manage their corporate cultures in this way make statements that national corporate government codes do not.

\section{References}

Aguilera, R.V. and Jackson, G. (2003), "The cross-national diversity of corporate governance: dimensions and determinants", Academy of Management Review, Vol. 28 No. 3, pp. 447-465.

Agyei-Mensah, B.K. (2017), "The relationship between corporate governance, corruption and forwardlooking information disclosure: a comparative study", Corporate Governance: The International Journal of Business in Society, Vol. 17 No. 2, pp. 284-304.

Alazzani, A., Hassanein, A. and Aljanadi, Y. (2017), "Impact of gender diversity on social and environmental performance: evidence from Malaysia", Corporate Governance: The International Journal of Business in Society, Vol. 17 No. 2, pp. 266-283.

Allaire, Y. and Firsirotu, M.E. (1984), "Theories of organizational culture", Organization Studies, Vol. 5 No. 3, pp. 193-226.

Ardichvili, A., Mitchell, J.A. and Jondle, D. (2009), "Characteristics of ethical business cultures", Journal of Business Ethics, Vol. 85 No. 4, pp. 445-451.

Azam, M., Khalid, M.U. and Zia, S.Z. (2019), "Board diversity and corporate social responsibility: the moderating role of shariah compliance", Corporate Governance: The International Journal of Business in Society, Vol. 19 No. 6, pp. 1274-1288.

Brad Shuck, M., Rocco, T.S. and Albornoz, C.A. (2011), "Exploring employee engagement from the employee perspective: implications for HRD", Journal of European Industrial Training, Vol. 35 No. 4, pp. 300-325. 
Brown, M.E., Treviño, L.K. and Harrison, D.A. (2005), "Ethical leadership: a social learning perspective for construct development and testing", Organizational Behavior and Human Decision Processes, Vol. 97 No. 2, pp. 117-134.

Cameron, K.S. and Quinn, R.E. (2005), Diagnosing and Changing Organizational Culture: Based on the Competing Values Framework, John Wiley \& Sons, San Francisco, CA.

Canals, J. (2014), "Global leadership development, strategic alignment and CEOs commitment", Journal of Management Development, Vol. 33 No. 5, pp. 487-502.

Cicon, J.E., Ferris, S.P., Kammel, A.J. and Noronha, G. (2012), "European corporate governance: a thematic analysis of national codes of governance", European Financial Management, Vol. 18 No. 4 , pp. 620-648.

Collins, J.C. and Porras, J.I. (2005), Built to Last: Successful Habits of Visionary Companies, Random House, New York, NY.

Denison, D.R., Haaland, S. and Goelzer, P. (2003), "Corporate culture and organizational effectiveness: is there a similar pattern around the world?", Advances in Global Leadership, Vol. 3, pp. 205-227.

Donaldson, T. and Walsh, J.P. (2015), "Toward a theory of business", Research in Organizational Behavior, Vol. 35, pp. 181-207.

Etzioni, A., (1988), The Moral Dimension: Toward a New Economics, Free Press, New York, NY.

Feldman, D.C. (1984), "The development and enforcement of group norms", Academy of Management Review, Vol. 9 No. 1, pp. 47-53.

Ferrero Ferrero, I. and Ackrill, R. (2016), "Europeanization and the soft law process of EU corporate governance: how has the 2003 action plan impacted on national corporate governance codes?", Journal of Common Market Studies, Vol. 54 No. 4, pp. 878-895.

Fiordelisi, F. and Ricci, O. (2014), "Corporate culture and CEO turnover", Journal of Corporate Finance, Vol. 28, pp. 66-82.

Gibbs, J.P. (1965), "Norms: the problem of definition and classification", American Journal of Sociology, Vol. 70 No. 5 , pp. 586-594.

Guiso, L., Sapienza, P. and Zingales, L. (2015), "The value of corporate culture", Journal of Financial Economics, Vol. 117 No. 1, pp. 60-76

Gundry, L.K. and Rousseau, D.M. (1994), "Critical incidents in communicating culture to newcomers: the meaning is the message", Human Relations, Vol. 47 No. 9, pp. 1063-1088.

Harris, S.G. and Mossholder, K.W. (1996), "The affective implications of perceived congruence with culture dimensions during organizational transformation", Journal of Management, Vol. 22 No. 4, pp. 527-547.

Haspeslagh, P. (2010), "Corporate governance and the current crisis", Corporate Governance: The International Journal of Business in Society, Vol. 10 No. 4, pp. 375-377.

Hatch, M.J. (1993), "The dynamics of organizational culture", Academy of Management Review, Vol. 18 No. 4, pp. 657-693.

Haxhi, I. and Van Ees, H. (2010), "Explaining diversity in the worldwide diffusion of codes of good governance", Journal of International Business Studies, Vol. 41 No. 4, pp. 710-726.

Hermes, N., Postma, T.J.B.M. and Zivkov, O. (2006), "Corporate governance codes in the European Union: are they driven by external or domestic forces?", International Journal of Managerial Finance, Vol. 2 No. 4, pp. 280-301.

Hofstede, G. (1983), "National cultures revisited", Behavior Science Research, Vol. 18 No. 4, pp. 285-305.

Humphries, S.A. and Whelan, C. (2017), "National culture and corporate governance codes", Corporate Governance: The International Journal of Business in Society, Vol. 17 No. 1, pp. 152-163.

Jackson, K. and Bazeley, P., (2019), Qualitative Data Analysis with Nvivo, SAGE Publications.

Jones, T.M., Felps, W. and Bigley, G.A. (2007), "Ethical theory and stakeholder-related decisions: the role of stakeholder culture", Academy of Management Review, Vol. 32 No. 1, pp. 137-155.

Kaptein, M. (2004), "Business codes of multinational firms: what do they say?", Journal of Business Ethics, Vol. 50 No. 1, pp. 13-31. 
Kaptein, M. (2011), "Understanding unethical behavior by unraveling ethical culture", Human Relations, Vol. 64 No. 6, pp. 843-869.

Kaptein, M. and Wempe, J.F.D.B. (2002), The Balanced Company: A Theory of Corporate Integrity, Oxford University Press, Oxford.

Karlsson, N.P.E., Laurell, H., Lindgren, J., Pehrsson, T., Andersson, S. and Svensson, G. (2018), "A cross-country comparison and validation of firms' stakeholder considerations in sustainable business practices", Corporate Governance: The International Journal of Business in Society, Vol. 18 No. 3, pp. 208-424.

Kotter, J.P. (2008), Corporate Culture and Performance, Simon and Schuster, New York, NY.

Kubícek, A., Štamfestová, P. and Strouhal, J. (2016), "Cross-country analysis of corporate governance codes in the European Union”, Economics \& Sociology, Vol. 9 No. 2, pp. 319-337.

Lai, J.Y.M., Lam, L.W. and Lam, S.S.K. (2013), "Organizational citizenship behavior in workgroups: a team cultural perspective", Journal of Organizational Behavior, Vol. 34 No. 7, pp. 1039-1056.

Li, J. and Harrison, J.R. (2008), "Corporate governance and national culture: a multi-country study", Corporate Governance: The International Journal of Business in Society, Vol. 8 No. 5, pp. 607-621.

Maier, R. and Schmidt, A. (2015), "Explaining organizational knowledge creation with a knowledge maturing model", Knowledge Management Research \& Practice, Vol. 13 No. 4, pp. 361-381.

Markos, S. and Sridevi, M.S. (2010), "Employee engagement: the key to improving performance", International Journal of Business and Management, Vol. 5 No. 12, pp. 89-96.

Neuendorf, K.A., (2002), The Content Analysis Guidebook, Sage Publications, Cleveland State University, USA.

Nicholson, G.J. and Kiel, G.C. (2004), "A framework for diagnosing board effectiveness", Corporate Governance, Vol. 12 No. 4, pp. 442-460.

O'Reilly, C.A., Chatman, J. and Caldwell, D.F. (1991), "People and organizational culture: a profile comparison approach to assessing person-organization fit", Academy of Management Journal, Vol. 34 No. 3, pp. 487-516.

Osma, B.G. and Guillamón-Saorín, E. (2011), "Corporate governance and impression management in annual results press releases", Accounting, Organizations and Society, Vol. 36 Nos 4/5, pp. 187-208.

Posner, B.Z., Kouzes, J.M. and Schmidt, W.H. (1985), "Shared values make a difference: an empirical test of corporate culture”, Human Resource Management, Vol. 24 No. 3, pp. 293-309.

Sabbaghi, O. (2016), "Corporate governance in China: a review", Corporate Governance: The International Journal of Business in Society, Vol. 16 No. 5, pp. 866-882.

Schein, E.H. (1984), "Coming to a new awareness of organizational culture", Sloan Management Review, Vol. 25 No. 2, pp. 3-16.

Schein, E.H., (2010), Organizational Culture and Leadership, John Wiley \& Sons, San Francisco, CA.

Schonfelder, K., Velamuri, S.R. and Liu, W. (2016), "Evolution of international and Chinese anti-bribery and corruption compliance programs", Corporate Governance: The International Journal of Business in Society, Vol. 16 No. 3, pp. 437-451.

Schwartz, H. and Davis, S.M. (1981), "Matching corporate culture and business strategy", Organizational Dynamics, Vol. 10 No. 1, pp. 30-48.

Silverzweig, S. and Allen, R.F. (1976), "Changing corporate culture", Sloan Management Review, Vol. 17 No. 3, pp. 33-49.

Soltani, B. (2014), "The anatomy of corporate fraud: a comparative analysis of high profile American and European corporate scandals", Journal of Business Ethics, Vol. 120 No. 2, pp. 251-274.

Soltani, B. and Maupetit, C. (2015), "Importance of core values of ethics, integrity and accountability in the European corporate governance codes", Journal of Management \& Governance, Vol. 19 No. 2, pp. 259-284.

Sorensen, J.B. (2002), "The strength of corporate culture and the reliability of firm performance", Administrative Science Quarterly, Vol. 47 No. 1, pp. 70-91. 
Treviño, L.K., Hartman, L.P. and Brown, M. (2000), "Moral person and moral manager: how executives develop a reputation for ethical leadership", California Management Review, Vol. 42 No. 4, pp. 128-142.

Verbeke, W., Volgering, M. and Hessels, M. (1998), "Exploring the conceptual expansion within the field of organizational behaviour: organizational climate and organizational culture", Journal of Management Studies, Vol. 35 No. 3, pp. 303-329.

Verhezen, P. (2010), "Giving voice in a culture of silence: from a culture of compliance to a culture of integrity", Journal of Business Ethics, Vol. 96 No. 2, pp. 187-206.

Webley, S. and Werner, A. (2008), "Corporate codes of ethics: necessary but not sufficient", Business Ethics: A European Review, Vol. 17 No. 4, pp. 405-415.

Wieland, J. (2005), "Corporate governance, values management, and standards: a European perspective", Business \& Society, Vol. 44 No. 1, pp. 74-93.

Yang, D. (2011), "How does knowledge sharing and governance mechanism affect innovation capabilities? From the coevolution perspective", International Business Research, Vol. 4 No. 1, pp. 154-157. 


\section{Appendix}

Table A1 Levels of incorporation per dimension for each code, in alphabetical order $(n=88)$

\begin{tabular}{|c|c|c|c|}
\hline National corporate governance code & $\begin{array}{l}\text { Layers of } \\
\text { corporate culture }\end{array}$ & $\begin{array}{l}\text { Alignment of } \\
\text { corporate culture }\end{array}$ & $\begin{array}{l}\text { Board's roles regarding } \\
\text { corporate culture }\end{array}$ \\
\hline Albania (2008) & Advanced & No & Minimal \\
\hline Armenia (2011) & Advanced & No & Medium \\
\hline Australia (2014) & Advanced & Advanced & Minimal \\
\hline Austria (2012) & Advanced & Advanced & No \\
\hline Azerbaijan (2011) & Medium & No & No \\
\hline Bahrein (2010) & Advanced & No & No \\
\hline Bangladesh (2012) & Medium & No & No \\
\hline Barbados (2013) & Advanced & Medium & Medium \\
\hline Belgium (2009) & Advanced & No & Minimal \\
\hline Bosnia and Herzegovina (2011) & Medium & Medium & No \\
\hline Brazil (2016) & Advanced & Advanced & Advanced \\
\hline Bulgaria (2012) & Medium & No & No \\
\hline Canada (2013) & Medium & No & Advanced \\
\hline China (2001) & Advanced & No & No \\
\hline Colombia (2004) & Medium & No & No \\
\hline Croatia (2010) & Advanced & No & No \\
\hline Cyprus (2012) & Medium & No & No \\
\hline Czech Republic (2004) & Advanced & Minimal & No \\
\hline Denmark (2014) & Advanced & Advanced & No \\
\hline Egypt (2011) & Medium & No & No \\
\hline Estonia (2006) & Advanced & Advanced & No \\
\hline Finland (2015) & Medium & No & Minimal \\
\hline France (2013) & Advanced & No & No \\
\hline Georgia (2009) & Medium & No & No \\
\hline Germany (2015) & Advanced & Advanced & No \\
\hline Ghana (2010) & Advanced & Advanced & Medium \\
\hline Greece (2013) & Advanced & No & Advanced \\
\hline Guernsey (2011) & Medium & No & No \\
\hline Hong Kong (2014) & Advanced & Medium & No \\
\hline Hungary (2012) & Medium & No & No \\
\hline Iceland (2015) & Medium & No & No \\
\hline India (2009) & Medium & No & No \\
\hline Indonesia (2007) & Advanced & Medium & Minimal \\
\hline Italy (2015) & Advanced & No & No \\
\hline Jamaica (2016) & Advanced & Medium & No \\
\hline Japan (2015) & Advanced & No & Advanced \\
\hline Jordan (2012) & Advanced & Advanced & Advanced \\
\hline Kazakhstan (2005) & Medium & No & No \\
\hline Kenya (2014) & Advanced & Advanced & Minimal \\
\hline Latvia (2010) & Advanced & No & No \\
\hline Lebanon (2006) & Advanced & No & No \\
\hline Lithuania (2006) & Advanced & No & No \\
\hline Luxembourg (2013) & Medium & No & No \\
\hline Macedonia (2006) & Medium & No & No \\
\hline Malawi (2010) & Medium & No & Advanced \\
\hline Malaysia (2012) & Medium & Advanced & Minimal \\
\hline Maldives (2014) & Medium & No & Minimal \\
\hline Malta (2014) & Medium & No & No \\
\hline Mauritius (2012) & Advanced & No & Minimal \\
\hline Mexico (1999) & Medium & No & No \\
\hline Moldova (2007) & Advanced & No & No \\
\hline \multirow[t]{2}{*}{ Mongolia (2007) } & Advanced & No & No \\
\hline & & & (continued) \\
\hline
\end{tabular}




\section{Table A1}

National corporate governance code

Layers of

Alignment of

Board's roles regarding

Montenegro (2009)

corporate culture

corporate culture

corporate culture

Morocco (2008)

The Netherlands (2016)

The Netherlands Antilles (2006)

New Zealand (2015)

Nigeria (2015)

Norway (2014)

Oman (2002)

Pakistan (2012)

Peru (2003)

Philippines (2016)

Poland (2015)

Portugal (2013)

Qatar (2009)

Romania (2015)

Russia (2014)

Saudi Arabia (2010)

Serbia (2008)

Singapore (2012)

Slovakia (2008)

Slovenia (2016)

South Africa (2009)

South Korea (2003)

Spain (2015)

Sri Lanka (2013)

Sweden (2015)

Switzerland (2014)

Taiwan (2010)

Thailand (2012)

Trinidad and Tobago (2013)

Tunisia (2008)

Turkey (2014)

UK (2014)

Ukraine (2003)

United Arab Emirates (2011)

USA (2013)

\section{Advanced}

Medium

Advanced

Medium

Advanced

Medium

Advanced

Advanced

Advanced

Advanced

Advanced

Medium

Advanced

Advanced

Medium

Advanced

Advanced

Medium

Advanced

Advanced

Advanced

Medium

Advanced

Advanced

Advanced

Advanced

Advanced

Advanced

Advanced

Advanced

Advanced

Advanced

Advanced

Advanced

Medium

Advanced

\section{No}

No

Advanced

No

Advanced

Advanced

No

No

Advanced

No

No

No

No

Advanced

No

No

No

No

No

No

No

Medium

No

No

No

No

No

No

No

Advanced

No

No

Advanced

No

No

No
No

No

Advanced

No

Advanced

Medium

No

No

Medium

No

Minimal

No

No

Medium

No

Medium

No

No

Minimal

No

Medium

Advanced

No

No

Minimal

Minimal

No

No

No

Medium

Advanced

No

Advanced

No

No

No

\section{Corresponding author}

Marie-Fleur Lobrij can be contacted at: lobrij@rsm.nl

For instructions on how to order reprints of this article, please visit our website:

www.emeraldgrouppublishing.com/licensing/reprints.htm

Or contact us for further details: permissions@emeraldinsight.com 